\title{
Seasonal changes in the taxonomic composition of bacterioplankton in a coastal oligotrophic system
}

\author{
Michael Schauer ${ }^{1,2}$, Vanessa Balagué ${ }^{1}$, Carlos Pedrós-Alióo ${ }^{1}$, Ramon Massana ${ }^{1, *}$ \\ ${ }^{1}$ Institut de Ciències del Mar, CMIMA, CSIC, Passeig Marítim de la Barceloneta 37-49, 08003 Barcelona, Catalonia, Spain \\ ${ }^{2}$ Present address: Institute for Limnology Mondsee, Austrian Academy of Sciences, Mondseestrasse 9, 5310 Mondsee, Austria
}

\begin{abstract}
The succession of taxa within the bacterioplankton assemblage was followed over a whole seasonal cycle in Blanes Bay, an oligotrophic coastal system (average chl a: $0.5 \mu \mathrm{g} \mathrm{l}^{-1}$ ) in the NW Mediterranean Sea. Phylogenetic composition of the bacterioplankton was studied by means of DGGE (denaturing gradient gel electrophoresis) and sequencing of predominant bands. Analysis of DGGE fingerprints showed gradual changes in the dominant bacterial members over the sampling period. The time scale during which a single population appeared in significant amounts in the system ranged between weeks and months. Most of the DGGE bands sequenced showed high similarities to sequences of uncultured marine bacteria. The bacterial assemblage appeared to be dominated by members of $\alpha$-Proteobacteria (mostly from the Roseobacter clade), Cytophaga-Flavobacteria-Bacteroides (CFB) and cyanobacteria throughout the year. Two bands related to prasinophyte chloroplasts were detected, whereas no bands related to SAR11 ( $\alpha$-Proteobacteria) or SAR86 ( $\gamma$-Proteobacteria) clusters were found. Contrasting with the relative stability of broad phylogenetic groups, examination of bands belonging to $\alpha$-Proteobacteria, CFB and cyanobacteria revealed a substitution of closely related phylotypes during the seasonal cycle within each one of these 3 groups. Overall, the taxonomic composition of the bacterioplankton in this coastal marine system appeared to be rather stable in time, showing gradual changes throughout the year.
\end{abstract}

KEY WORDS: Marine bacteria $\cdot$ DGGE $\cdot$ Fingerprinting $\cdot 16 \mathrm{~S}$ rDNA $\cdot$ Seasonal succession Resale or republication not permitted without written consent of the publisher

\section{INTRODUCTION}

Heterotrophic planktonic bacteria have a wellknown role in carbon and inorganic nutrient cycling in marine environments. Traditionally, they have been treated as a uniform functional group with little concern for the identity of the populations within it. During the last decade this situation has changed (Giovannoni \& Rappé 2000), and an understanding of the biogeochemical implications of the assemblage's taxonomic composition is beginning to emerge (Cottrell \& Kirchman 2000a). In addition to detailed descriptions of the bacterial populations that dominate a given sample, it is fundamental to understand how these populations are distributed in time and space in the environment. Some studies have addressed the spatial scales of variation of marine bacterioplankton assemblages (Murray et al. 1998, Riemann et al. 1999, Schauer et al. 2000, Bano \& Hollibaugh 2002, Riemann \& Middelboe 2002). These studies suggest rather modest changes of the bacterial community over large horizontal scales, resulting in a relatively stable community composition over wide areas. Variation along vertical profiles has been shown to be more marked, with distinct assemblages at different depths (Acinas et al. 1997, Murray et al. 1998). Data on temporal variability are still more scarce and limited. Temporal changes have the potential to be very rapid, as was demonstrated in several mesocosm experiments that showed dramatic changes in the composition of the bacterial assemblage on daily to weekly time scales (van Hannen et al. 1999, Schäfer et al. 2001). It is not clear whether these changes are frequent in the field, although in some situations, such as during phytoplankton blooms, strong changes in 
numbers and phylogenetic shifts of the bacterial assemblage have been observed (Fandino et al. 2001, Yager et al. 2001). Only a handful of studies have addressed temporal changes during a whole seasonal cycle in natural environments and, due to the difficulties of sampling year-round in the sea, they have been carried out mostly in freshwater (Lindström 1998, Pernthaler et al. 1998) or coastal (Murray et al. 1998, Pinhassi \& Hagström 2000) environments. Changes in the bacterial taxonomic structure have been observed in all these studies, but a clear picture of bacterial succession and the scale of temporal changes for most marine environments is still lacking.

In the present work we chose Blanes Bay (NW Mediterranean) as a model system to study the succession of the bacterioplankton in relatively oligotrophic sites (low nutrient concentration and low plankton biomass). The site has been investigated for several years and a reasonably good knowledge of seasonal changes in physico-chemical variables and plankton organisms is available (Duarte et al. 1999 and references therein). The shallow waters of Blanes Bay are vertically mixed, with salinities ranging from $37.0 \mathrm{psu}$, typical of Mediterranean coastal surface waters, to $38.4 \mathrm{psu}$, typical of open sea surface waters that can intrude on the coast due to the influence of a nearby submarine canyon. Episodic intrusions of lower salinity water can occur due to rainfall or the influence of the Rhone River plume (Masó \& Tintoré 1991). In Blanes Bay there is a marked seasonality of water temperature and solar radiation, typical of temperate zones, and this affects species composition of the planktonic assemblages. Highest chl a concentrations are found during phytoplankton blooms in February and March, coincident with periods of particular weather stability, and bacterial abundance reaches maximal numbers shortly after these blooms (Vaqué et al. 1997). We have previously shown that different bacterial assemblages are found in different seasons of the year (Schauer et al. 2000). The latter study also reported relatively similar bacterial assemblages over 10s of kilometers along the Catalan Coast, suggesting that the data obtained in Blanes Bay may be viewed as characteristic of a more general coastal situation.

The aim of this work was to determine the phylogenetic composition and temporal dynamics of the bacterial assemblage in Blanes Bay. In particular, we were interested in determining the time scale of changes in the dominant bacterial populations. We chose an approach based on the PCR amplification of bacterial 16S rRNA genes and separation of fragments from different taxa by DGGE (Murray et al. 1996, Muyzer et al. 1997). The fingerprint provides a graphical representation of the composition of a given bacterial assemblage, allowing for a rapid visual comparison of samples varying over space or time. Moreover, spe- cific members of the bacterial assemblage can subsequently be identified by sequencing excised bands, and therefore the dynamics of particular populations can be followed in detail.

\section{MATERIALS AND METHODS}

Study area and sampling. Sampling was performed in Blanes Bay on the Catalan coast (NW Mediterranean, $\left.41^{\circ} 40^{\prime} \mathrm{N}, 2^{\circ} 48^{\prime} \mathrm{E}\right)$. The site was $800 \mathrm{~m}$ offshore and had a sand bottom at around $20 \mathrm{~m}$ depth. Extensive background information exists about this site (Duarte et al. 1999). Surface samples were collected once a month between December 1997 and December 1998, except in February and March 1998 when they were taken on a weekly basis. Surface water temperature was measured in situ with a thermometer. Seawater was kept in $25 \mathrm{l}$ plastic carboys for less than $2 \mathrm{~h}$ during transport until it was processed in the laboratory. To collect microbial biomass, between 5 and 151 of seawater were filtered using a peristaltic pump through a $5 \mu \mathrm{m}$ pore size Durapore filter (Millipore) and a $0.2 \mu \mathrm{m}$ Sterivex filter (Durapore, Millipore) in succession. The Sterivex unit was filled with $1.8 \mathrm{ml}$ of lysis buffer (40 mM EDTA, $50 \mathrm{mM}$ Tris- $\mathrm{HCl}, 0.75 \mathrm{M}$ sucrose) and stored at $-70^{\circ} \mathrm{C}$. Chl a concentrations were determined by measuring the fluorescence in acetone extracts with a Turner Designs fluorometer (Yentsch \& Menzel 1963). Briefly, 50 to $150 \mathrm{ml}$ of seawater were filtered on GF/F filters (Whatman). The filters were extracted in acetone $(90 \% \mathrm{v} / \mathrm{v})$ in the dark at $4^{\circ} \mathrm{C}$ for $24 \mathrm{~h}$ before measuring the fluorescence. Subsamples for determination of prokaryote abundance were fixed with paraformaldehyde and glutaraldehyde (final concentrations 1 and $0.05 \%$, respectively) and allowed to sit in the dark for $10 \mathrm{~min}$ prior to transferring them to liquid nitrogen. Counting of prokaryotes was performed in a FACScalibur flow cytometer (Becton \& Dickinson) after staining cells with Syto13 (Molecular Probes) following the procedure outlined in Gasol \& del Giorgio (2000). The coefficient of variation of prokaryotic counts was always below 5\%. Synechococcus, Prochlorococcus and photosynthetic picoeukaryotes were distinguished by their different size and pigment properties in unstained aliquots as explained in Olsen et al. (1993). Synechococcus and Prochlorococcus were on average below $3.5 \%$ of total prokaryotic counts.

DNA extraction and purification. Nucleic acid extraction began by adding lysozyme $\left(1 \mathrm{mg} \mathrm{ml}^{-1}\right)$ to the Sterivex filter unit and incubating at $37^{\circ} \mathrm{C}$ for $45 \mathrm{~min}$. Subsequently, Proteinase K $\left(0.2 \mathrm{mg} \mathrm{ml}^{-1}\right)$ and sodium dodecyl sulphate (SDS, $1 \%$ ) were added, and the filter was incubated at $55^{\circ} \mathrm{C}$ for $1 \mathrm{~h}$. The lysate was recov- 
ered from the filter and the filter was rinsed with $1 \mathrm{ml}$ of lysis buffer. The pooled lysates were then extracted twice with an equal amount of phenol-chloroformisoamyl alcohol (25:24:1, pH 8) and once with an equal amount of chloroform-isoamyl alcohol (24:1). The aqueous phase was spun down in a micro concentrator (Centricon-100, Millipore), washed with sterile TE buffer several times and reduced to a volume of 100 to $200 \mu \mathrm{l}$. The recovered DNA was quantified by a Hoechst dye fluorescence assay (Paul \& Myers 1982), and the quality of the DNA was checked by agarose gel electrophoresis. Extractions yielded between 0.6 and $3.1 \mu \mathrm{g}$ DNA per liter of sample. Nucleic acid extracts were stored at $-70^{\circ} \mathrm{C}$.

PCR and DGGE. One ng of microbial DNA was used as template for PCR amplification of bacterial 16S rDNA. The reactions (50 $\mu \mathrm{l}$ volume) contained $200 \mu \mathrm{M}$ of each of the deoxynucleoside triphosphates, $0.3 \mu \mathrm{M}$ of each of the primers, $1.5 \mathrm{mM} \mathrm{MgCl}_{2}, 1 \times$ PCR-buffer and 1 Unit of Taq DNA Polymerase (GIBCO BRL). We used the bacterial specific primer 358f $\left(5^{\prime}\right.$-CCT ACG GGA GGC AGC AG-3'), with a 40 bp GC-clamp, and the universal primer $907 \mathrm{rC}$ (5'-CCG TCA ATT CCT TTR AGT TT-3'), which amplifies a 550 bp DNA fragment of bacterial 16S rDNA (Muyzer et al. 1997). In a few cases (see 'Discussion') we also used primer 907rM (5'-CCG TCA ATT CMT TTG AGT TT-3'). The PCR was performed with a Genius thermal cycler (Techne) using the following program: initial denaturation at $94^{\circ} \mathrm{C}$ for $5 \mathrm{~min} ; 10$ touchdown cycles of denaturation (at $94^{\circ} \mathrm{C}$ for $1 \mathrm{~min}$ ), annealing (at 65 to $55^{\circ} \mathrm{C}$ for $1 \mathrm{~min}$, decreasing $1^{\circ} \mathrm{C}$ each cycle) and extension (at $72^{\circ} \mathrm{C}$ for $3 \mathrm{~min}$ ); 20 standard cycles of denaturation (at $94^{\circ} \mathrm{C}$ for $1 \mathrm{~min}$ ), annealing (at $55^{\circ} \mathrm{C}$ for $1 \mathrm{~min}$ ) and extension (at $72^{\circ} \mathrm{C}$ for $3 \mathrm{~min}$ ), and a final extension at $72^{\circ} \mathrm{C}$ for $5 \mathrm{~min}$. PCR products were verified and quantified by agarose gel electrophoresis with a standard in the gel (Low DNA Mass Ladder, GIBCO BRL).

DGGE was carried out with a DGGE-2000 system (CBS Scientific Company) as described in Muyzer et al. (1997). A 6\% polyacrylamide gel with a gradient of DNA-denaturant agent was casted by mixing solutions of 40 and $80 \%$ denaturant agent $(100 \%$ denaturant agent is $7 \mathrm{M}$ urea and $40 \%$ deionized formamide). $800 \mathrm{ng}$ of PCR product was loaded for each sample and the gel was run at $100 \mathrm{~V}$ for $16 \mathrm{~h}$ at $60^{\circ} \mathrm{C}$ in $1 \times \mathrm{TAE}$ buffer (40 mM Tris [pH 7.4], $20 \mathrm{mM}$ sodium acetate, $1 \mathrm{mM}$ EDTA). The gel was stained with the nucleic acid stain SybrGold (Molecular Probes) for $45 \mathrm{~min}$, rinsed with $1 \times$ TAE buffer, removed from the glass plate to a UV transparent gel scoop, and visualized with UV in a Fluor-S MultiImager (Bio-Rad) with the Multi-Analyst software (Bio-Rad). High-resolution images $(1312 \times 1034$ pixels, 12-bits dynamic range) were saved as computer files.
Sequencing and phylogenetic analysis. DGGE bands were excised from the gel and kept in $20 \mu \mathrm{l}$ of MilliQ water overnight. Five $\mu \mathrm{l}$ of the supernatant were used for reamplification with the original primer set. A part of the PCR product was checked by DGGE together with the original sample to verify the correct position of the band, and in the few cases that it yielded more than one band it was processed again as described above. PCR products were purified with the QIAquick PCR-Purification Kit (QIAGEN) and quantified in an agarose gel. Approximately 10 to $20 \mathrm{ng}$ were used for the sequencing reaction, using primer $358 \mathrm{f}$ without the GC-clamp, with the Bigdye Terminator Cycle Sequencing Kit v2.0 (PE Biosystems) and an ABI PRISM model 377 (v3.3) automated sequencer. The sequences obtained (normally between 400 and $500 \mathrm{bp}$, see Table 1) were compared with public database DNA sequences using BLAST (Altschul et al. 1997) to determine their phylogenetic affiliation. The check_chimera command of the Ribosomal Database Project (Maidak et al. 2001) was used to rule out possible chimerical structures in our sequences. Partial sequences were aligned with about 5400 homologous complete prokaryotic 16S rRNA primary structures using the automated aligning tool of the ARB program package (Technical University of Munich; http:// www.arb-home.de/). A similarity matrix was constructed to get sequence similarity values. The aligned sequences were inserted into the optimized tree derived from complete sequence data by using the quick add parsimony tool, which does not affect the initial tree topology. The resulting tree was pruned to save space, and the closest relatives were retained.

Quantitative analysis of DGGE fingerprints. Digitized DGGE images were analyzed with the Diversity Database software (Bio-Rad). The software performs a density profile through each DGGE lane, detects the bands, and calculates the relative contribution of each band to the total band signal in the lane after applying a rolling disk as background subtraction. Bands with a relative intensity of less than $0.2 \%$ were discarded. The bands occupying the same position in the different lanes of the gel were identified. A matrix was constructed taking into account the presence or absence of individual bands in each lane and the relative contribution of the band (in percentage) to the total intensity of the lane. This matrix was used to calculate a distance matrix using Euclidean distances (root-meansquared differences) with the software Statistica 99 (StatSoft). A dendrogram comparing samples was obtained by UPGMA (unweighted pair-group method with arithmetic averages) in cluster analysis (Statistica 99). The distance matrix was also used for constructing a nonmetric multidimensional scaling (NMDS) diagram (Statistica 99). This data-reducing method places 


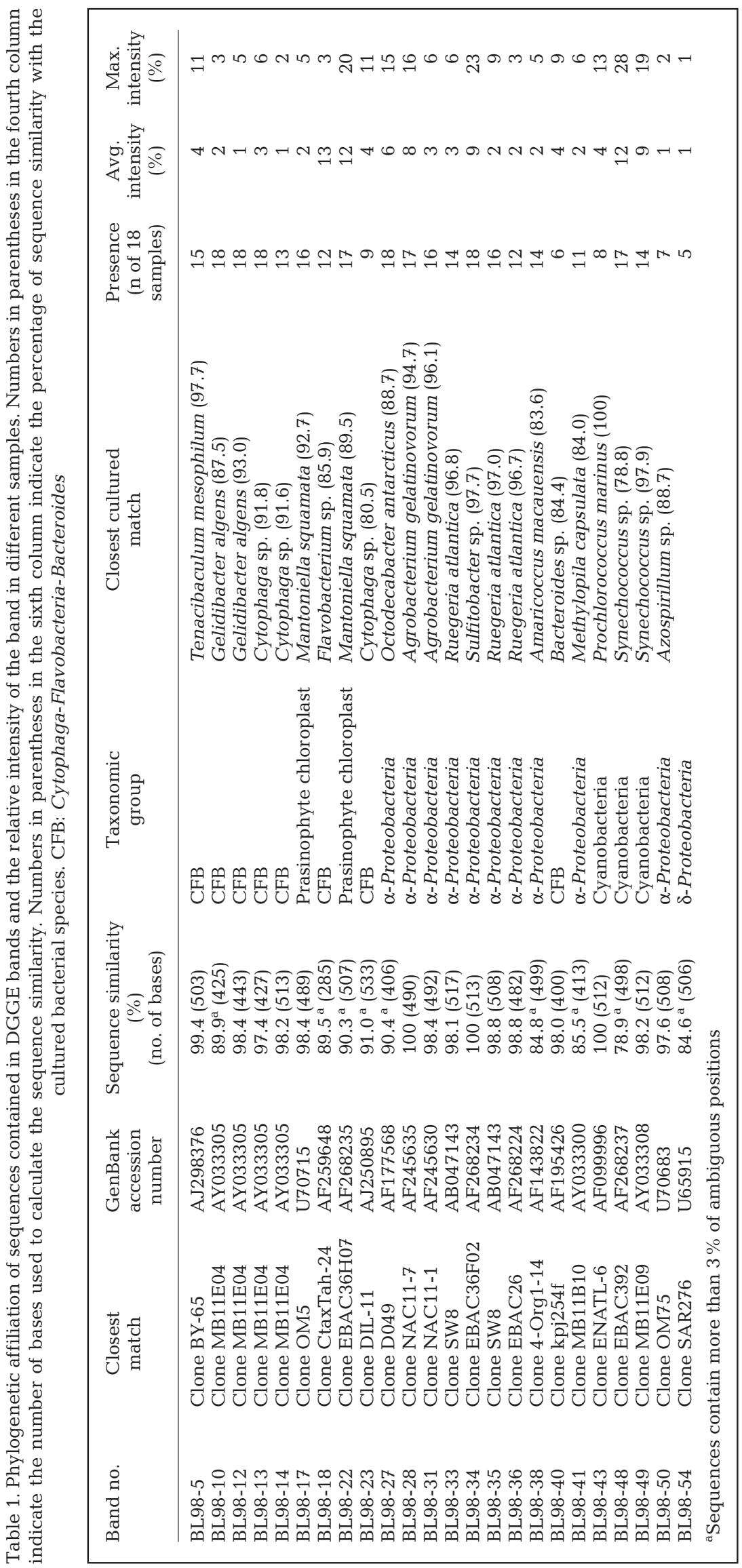

each complex DGGE fingerprint as 1 point in a 2D diagram with artificial $x$ - and $y$-axes, in a way that more similar samples are plotted closer together (van Hannen et al. 1999).

\section{RESULTS}

Sampling from December 1997 to December 1998 resulted in a total of 18 samples. Surface water temperature showed a marked seasonality, with minimal values during winter $\left(13^{\circ} \mathrm{C}\right)$ and maximal values at the end of summer $\left(27^{\circ} \mathrm{C}\right)$ (Fig. 1). Phytoplankton biomass (chl a values) peaked from February to April (up to $2 \mu \mathrm{g} \mathrm{l}^{-1}$ ) and showed lower and rather constant values ( 0.1 to $0.5 \mathrm{\mu g} \mathrm{l}^{-1}$ ) for the rest of the sampling period. The phytoplankton fraction passing the prefilter unit ( $\mathrm{chl} a<5 \mu \mathrm{m}$ ) ranged from 0.01 to $0.39 \mathrm{\mu g} \mathrm{l}^{-1}$ (average $0.15 \mu \mathrm{g} \mathrm{l}^{-1}$ ) and represented between 3 and $43 \%$ of total chl a (Fig. 1). Prokaryote numbers tripled after both the winter and spring phytoplankton blooms, with a delay of 1 to $2 \mathrm{wk}$, maintaining numbers at ca. $5 \times 10^{5}$ cells ml ${ }^{-1}$ during the rest of the year (Fig. 2A). Synechococcus peaked from spring to late summer, contributing up to $7 \%$ of total prokaryote numbers (Fig. 2B). Prochlorococcus was generally found in lower numbers, as expected for a coastal environment. This population showed highest numbers in fall and winter when Synechococcus started to decline, and contributed up to $3 \%$ of total prokaryote numbers (Fig. 2B). Photosynthetic picoeukaryotes, on the other hand, were more abundant in spring (up to 5000 cells ml$^{-1}$ ), slowly declining over summer with minimal values in fall and winter (Fig. 2B).

The 18 samples taken over the annual cycle were run in 2 DGGE gels (Fig. 3). Four samples were run in both gels to allow for comparison among the gels. Thus, positions of the bands in different gels could be unambiguously identified and connected with thin lines in Fig. 3. The analysis of the gels gave a total of 545 


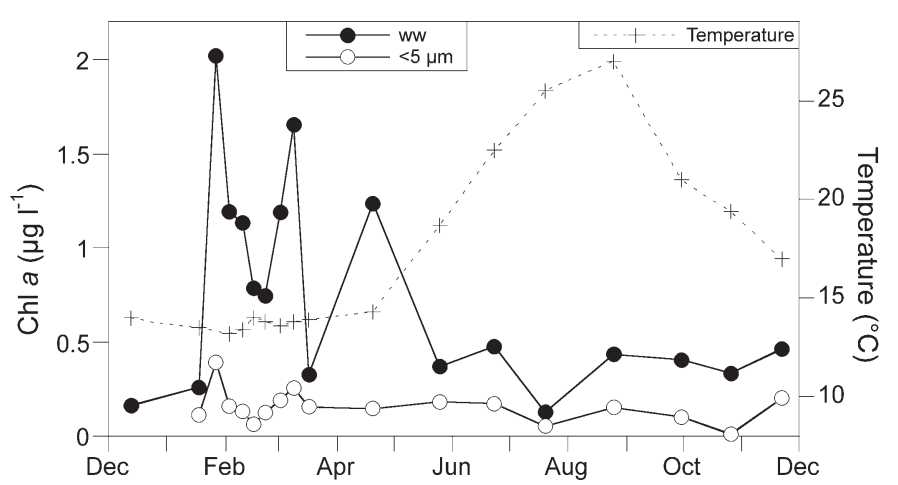

Fig. 1. Temperature and chl a content of whole water (ww) and the fraction passing the $5 \mu \mathrm{m}$ prefilter of Blanes Bay surface samples from December 1997 to December 1998

detectable bands in 57 different positions. The number of bands per sample varied between 26 and 36 (mean 30.2). We found no correlations between the number of bands detected and the abundance of prokaryotes or the chl a concentration in the sample.

On the basis of the intensity matrix (presence and relative intensity of DGGE bands in all samples), we used nonmetric multidimensional scaling (NMDS) to show the differences of DGGE fingerprints in a diagram. Consecutive samples were connected by lines in order to follow the changes of the bacterial assemblage along the sampling period (Fig. 4). The composition of the bacterial assemblage changed gradually, and in
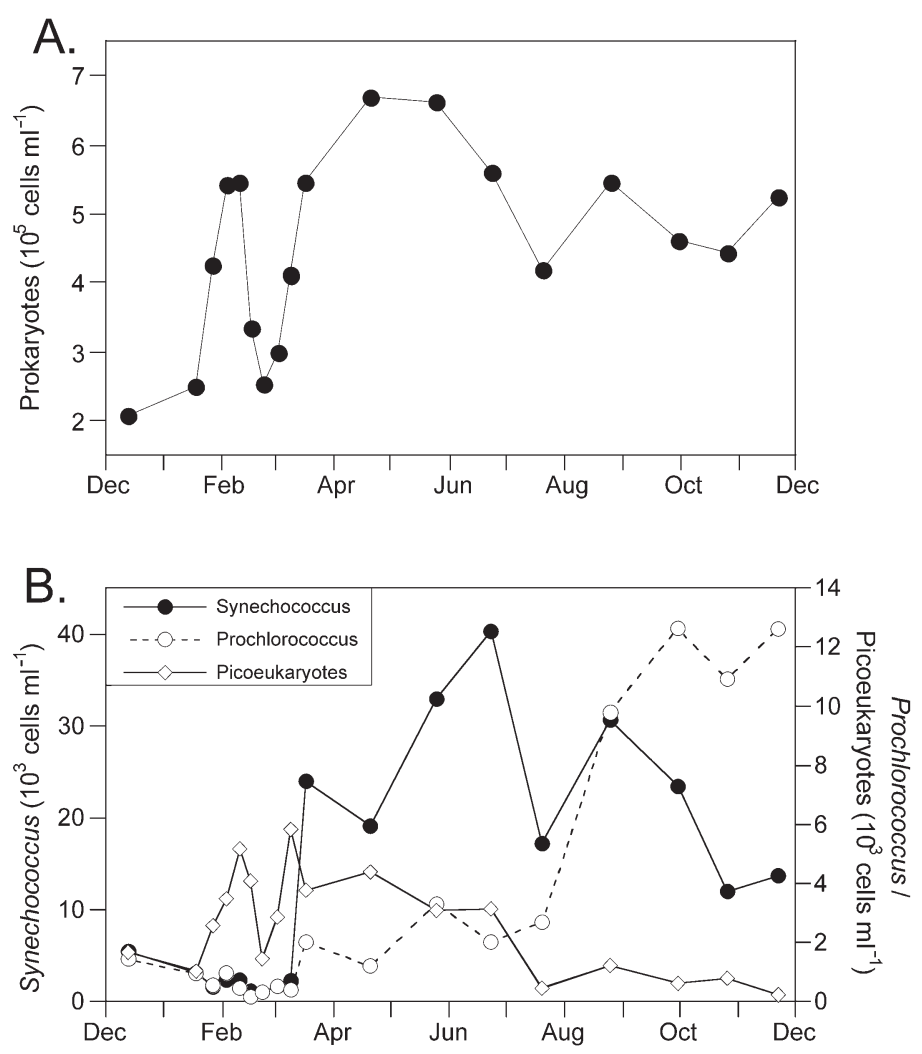

Fig. 2. Abundance of different picoplankton groups in surface samples from Blanes Bay assessed by flow cytometry over the seasonal cycle. (A) Total prokaryotes; (B) photosynthetic groups

(Synechococcus, Prochlorococcus and picoeukaryotes)

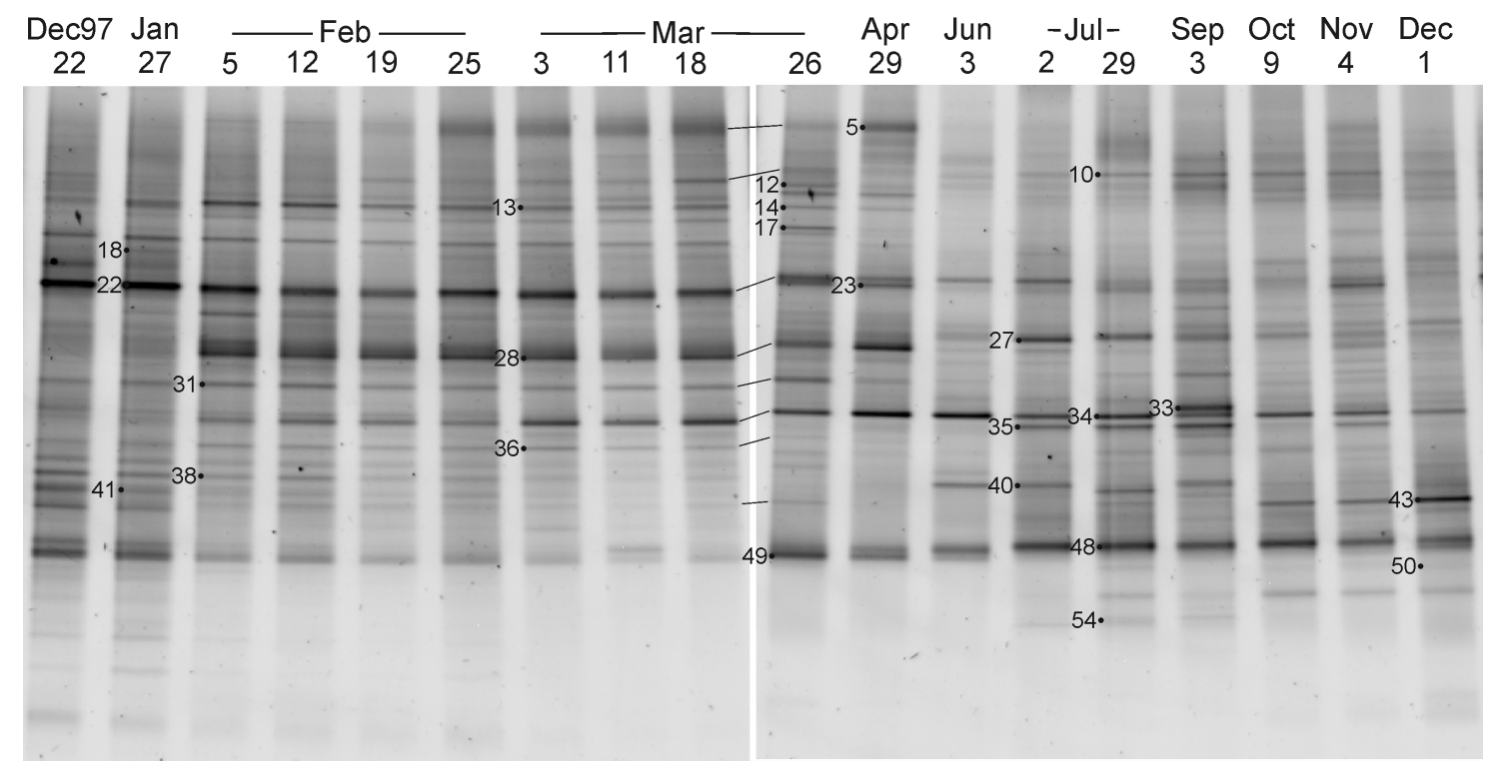

Fig. 3. Negative images of DGGE (denaturing gradient gel electrophoresis) gels containing bacterial 16S rRNA fragments (PCR amplified with primers $358 \mathrm{f}$ and $907 \mathrm{rC}$ ) from Blanes Bay samples. The portions of images of 2 analyzed gels were cut and printed side by side and the corresponding band positions in each gel were connected by thin lines. Numbers in the gels mark excised and sequenced bands according to their position in the intensity matrix 


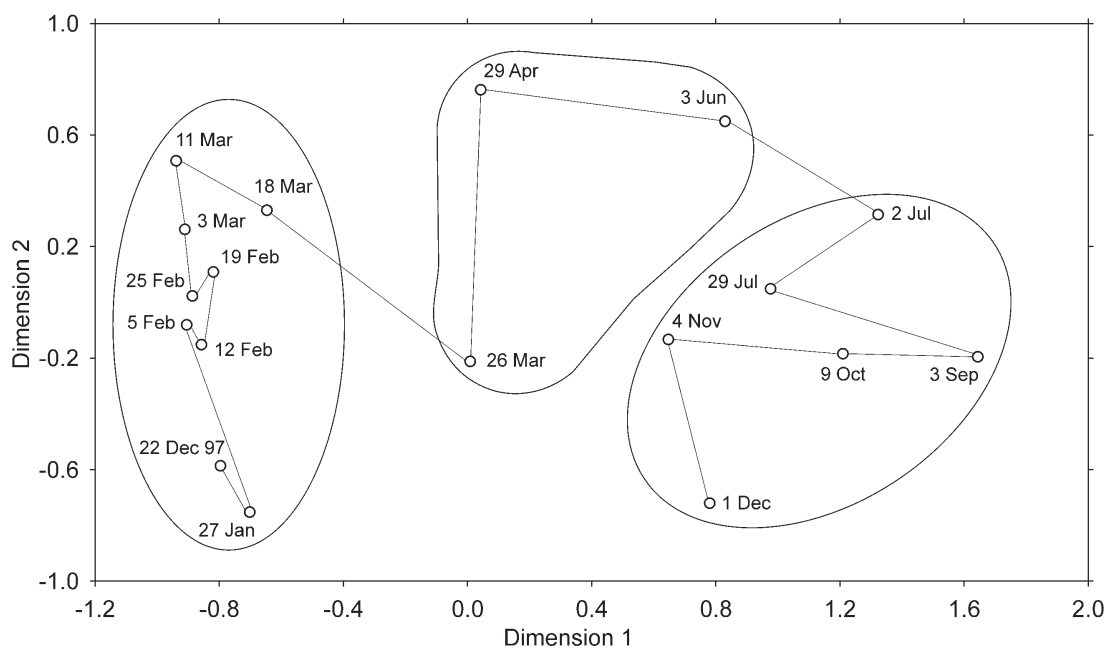

Fig. 4. Nonmetric multidimensional scaling (NMDS) diagram representing the changes in bacterial community structure in Blanes Bay during the seasonal cycle. Consecutive samples are connected by lines. Encircled areas include samples that group together in a dendrogram obtained with the same data set general there was neither exactly the same assemblage at consecutive samplings nor abrupt changes between consecutive dates. The increased sampling frequency (weekly) during February and March resulted in a close association of these samples in the diagram, although there were more pronounced changes in bacterial assemblage structure from samples taken 27 January to 5 February and 18 to 26 March. The same intensity matrix was also used as a basis for cluster analysis (dendrogram not shown). Encircled areas in Fig. 4 contain samples as grouped by the cluster analysis. Samples from December 1997 to mid-March 1998 formed a winter cluster. Samples from the end of March to the beginning of June 1998 belonging to a transition period with marked changes in the bacterial assem-

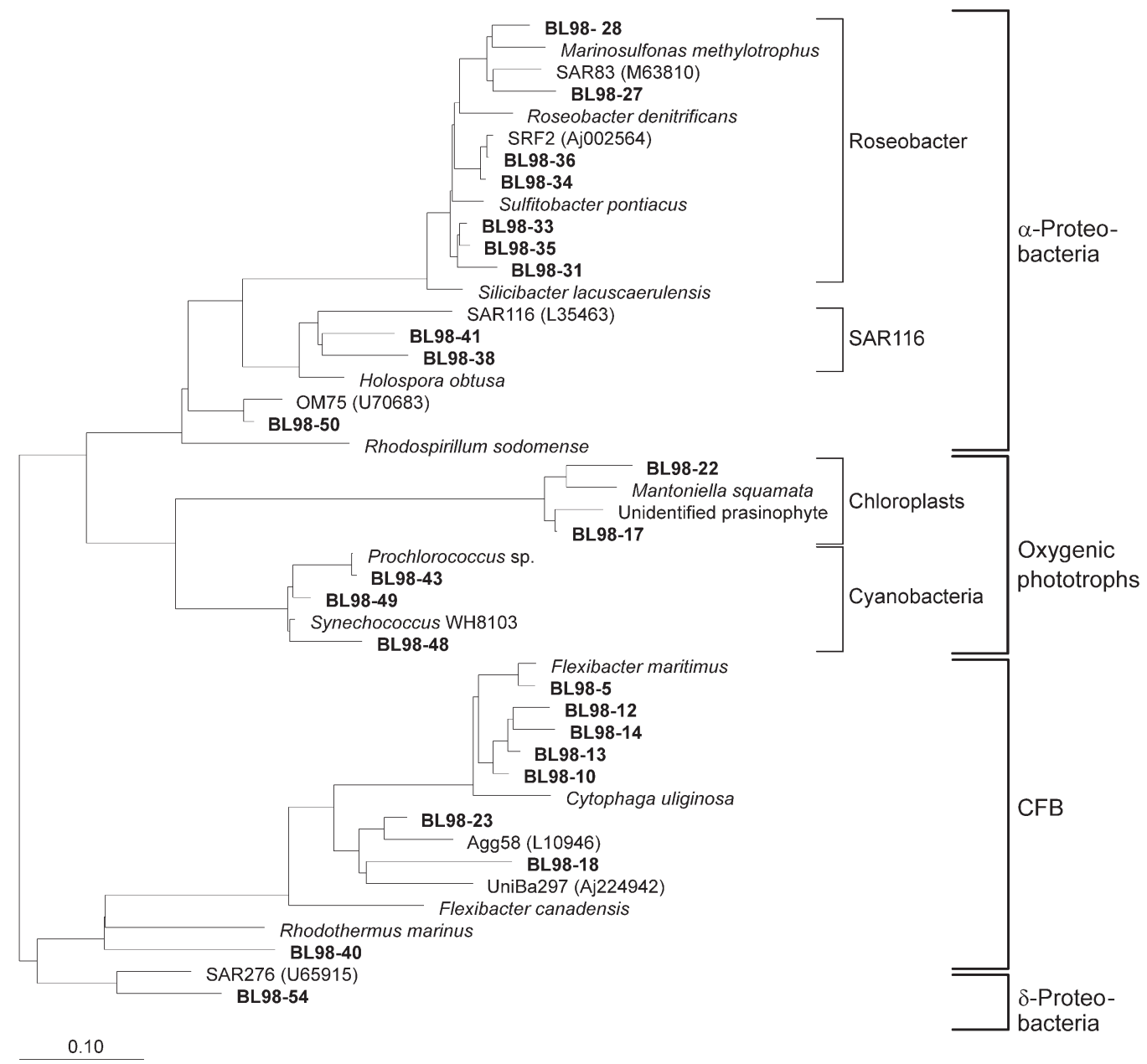

Fig. 5. Phylogenetic affiliation of the sequences retrieved from DGGE (denaturing gradient gel electrophoresis) bands marked in Fig. 3. The tree was constructed by adding partial sequences by parsimony analysis to a previously validated and optimized tree.The scale bar indicates $10 \%$ estimated sequence divergence 


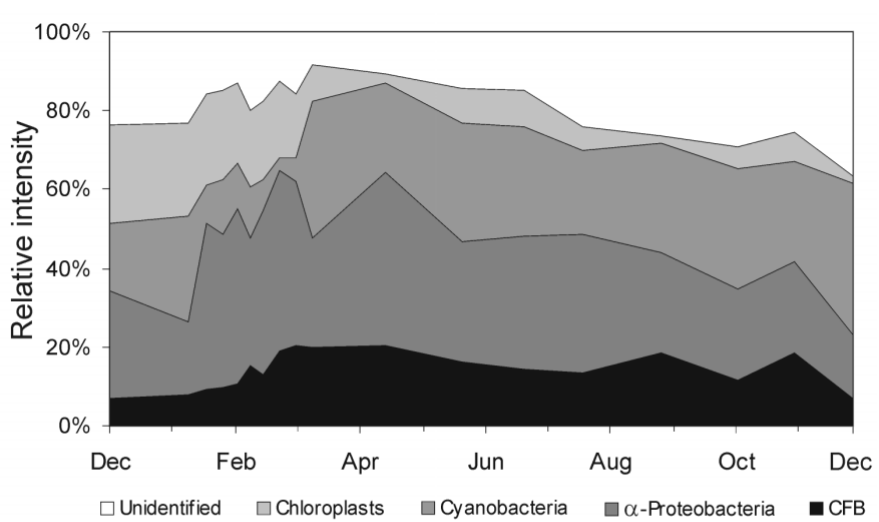

Fig. 6. Relative intensity (based on DGGE [denaturing gradient gel electrophoresis] band intensity) of broad phylogenetic groups during the Blanes Bay seasonal cycle. Cytophaga-Flavobacteria-Bacteroides (CFB) includes 8 bands, $\alpha$-Proteobacteria 10 bands, cyanobacteria 3 bands, and chloroplasts 2 bands (34 bands remained unidentified)

blage were loosely associated in a spring cluster. A summer/fall cluster included samples from July to December. In comparable time-series studies done in 2 other sites along the Catalan coast (Masnou and Barcelona, 50 and $70 \mathrm{~km}$ south of Blanes, respectively), we found similar gradual changes and sample groups in DGGE fingerprints (data not shown).

We excised and sequenced 24 bands in different positions of the gel (see numbers in Fig. 3). These bands accounted for 63 to $92 \%$ (mean $81 \%$ ) of the total band intensity in each lane, and therefore accounted for most of the DGGE signal. A BLAST search was used to determine their closest sequences in public databases (Table 1). Most of the DGGE bands showed high similarities (97 to $100 \%$ ) to clones previously retrieved from marine environments. The cases with similarity to environmental clones lower than $97 \%$ were due to the presence of ambiguities in the sequence (Table 1). The similarity was significantly lower when comparing with cultured strains (Table 1), indicating that the retrieved sequences, with the remarkable exception of cyanobacteria, represent currently uncultured taxa. Sequenced DGGE bands were added to a tree of bacterial 16S rDNA sequences in order to visualize the relationships among them (Fig. 5). Out of the 24 sequenced bands, 8 bands belonged to the CytophagaFlavobacteria-Bacteroides group (CFB). Of these, 4 bands that migrated close together in the DGGE gel (BL98-10, -12, -13 and -14, Fig. 3) were closely related (sequence similarities between 96.5 and $99.5 \%$ ). Eleven bands belonged to Proteobacteria, 10 bands to the $\alpha$ subclass ( 7 to the Roseobacter clade and 2 to the SAR116 cluster), and 1 band to the $\delta$ subclass. Within the Roseobacter clade, 5 bands (BL98-31, -33, -34, -35 and -36) were highly related (sequence similarities
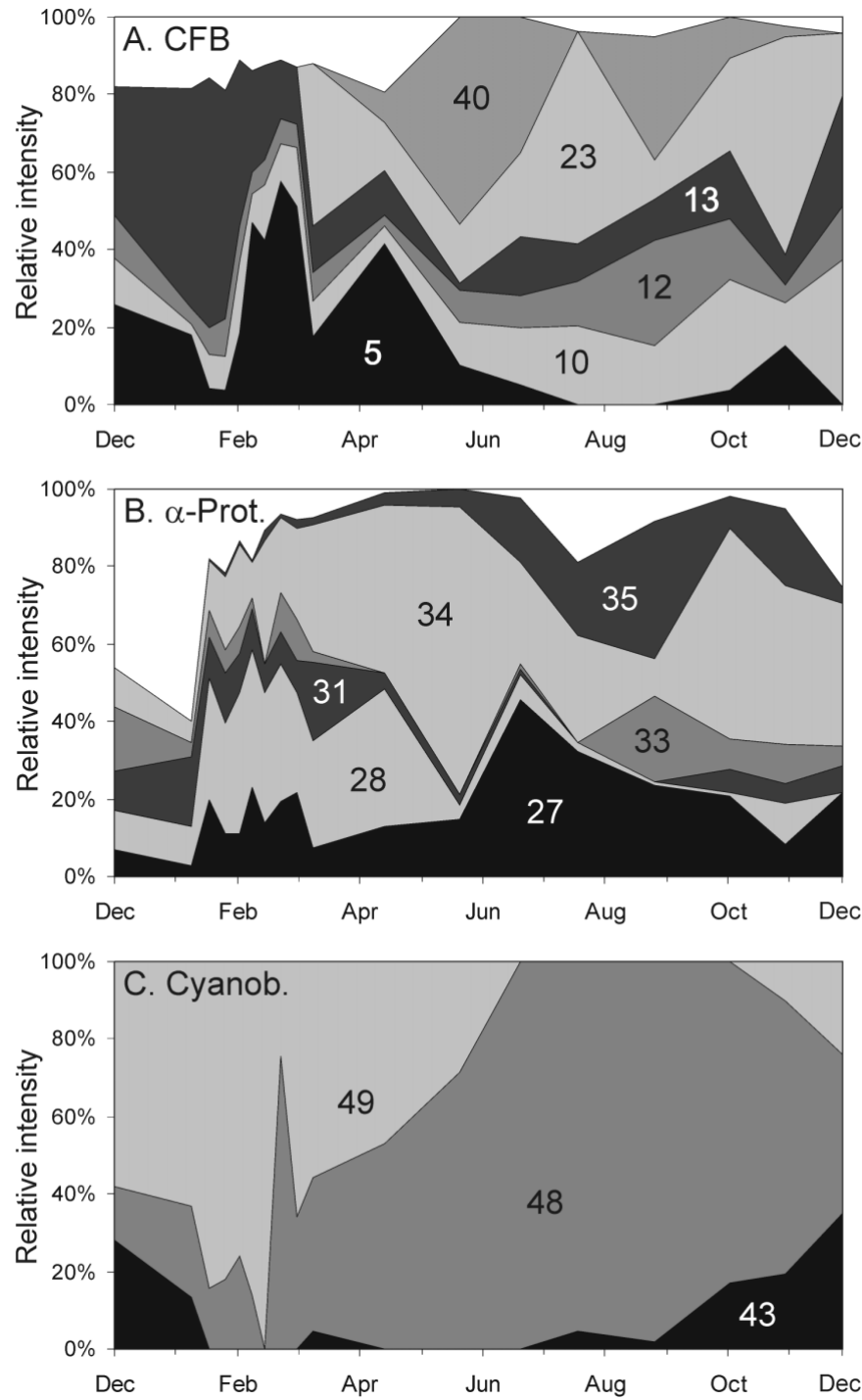

Fig. 7. Recalculated relative intensity of sequenced bands inside broad phylogenetic groups. Numbers in the diagram correspond to the DGGE (denaturing gradient gel electrophoresis) band number. Intensities of bands not shown were added up and represented by the white area. (A) Cytophaga-Flavobacteria-Bacteroides (CFB); (B) $\alpha$-Proteobacteria; (C) cyanobacteria

between 95.9 and $99.4 \%$ ), while the other 2 bands (BL98-27 and -28) showed sequence similarities of around $94 \%$ in relation to this cluster. Cyanobacteria were present with 2 bands related to Synechococcus sp. and 1 band with the same sequence as Prochlorococcus marinus. Finally, 2 of the bands sequenced were closely related to prasinophyte chloroplasts.

The contribution of the main phylogenetic groups to total DGGE band intensity did not change dramatically throughout the year (Fig. 6). Thus, bands affiliating with $\alpha$-Proteobacteria contributed between 16 and 

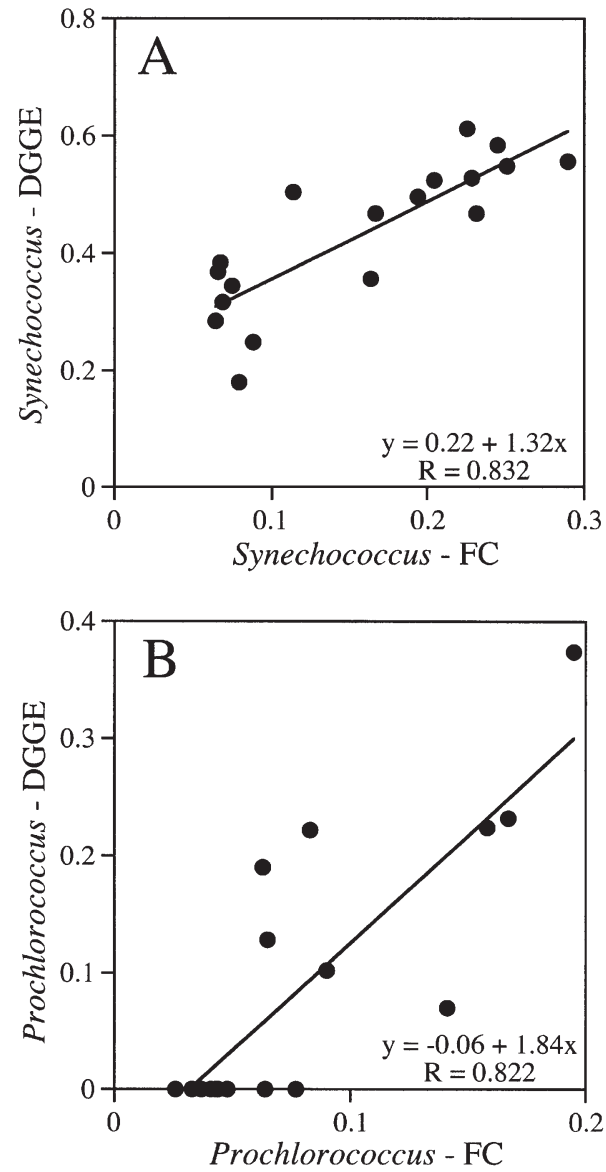

Fig. 8. Correlation between the relative abundance by flow cytometry (FC) and the relative intensity of the corresponding DGGE (denaturing gradient gel electrophoresis) bands for (A) Synechococcus and (B) Prochlorococcus. Data from all sampling points have been normalized by the arcsine transformation

$46 \%$ of total band intensity on different sampling days (mean of $33 \%$ ); CFB bands between 7 and $21 \%$ (mean of $14 \%)$; cyanobacterial bands between 3 and $38 \%$ (mean of $20 \%$ ); and chloroplast bands between 2 and $25 \%$ (mean of $13 \%$ ). The range was largest for the latter 2 groups, with low values for cyanobacteria and high for chloroplasts during winter and the reverse situation in summer. This agrees well with the trends of the respective populations observed by direct counts (Fig. 2B). In contrast to the relative constancy in band intensity of broad phylogenetic groups, there was large variability in the intensity of particular bands within each group (Fig. 7). Thus, the CFB (Fig. 7A), $\alpha-$ Proteobacteria (Fig. 7B) and cyanobacteria assemblages (Fig. 7C) were composed of distinct phylotypes that replaced each other during the seasonal cycle. Within the CFB group, Band BL98-13 dominated in winter, BL98-5 peaked in spring, and BL98-40 and
BL98-23 dominated one after the other in summer and fall (Fig. 7A). Within the $\alpha$-Proteobacteria, Band BL9828 dominated in spring, followed by BL98-34 in late spring, BL98-27 during summer and BL98-35 and BL98-34 in fall (Fig. 7B). Synechococcus phylotypes dominated the cyanobacteria, BL98-49 during winter and spring and BL98-48 in summer and autumn, whereas the band related to Prochlorococcus (BL9843) showed a small peak in winter (Fig. 7C).

\section{DISCUSSION}

\section{Methodological considerations}

We have used the presence and relative intensity of DGGE bands to analyze the phylogenetic composition and temporal variability of bacterioplankton. We are aware of potential PCR biases (von Witzingerode et al. 1997), especially those that affect the final ratios of PCR amplicons (Suzuki \& Giovannoni 1996), thus compromising quantitative interpretations. This is why we never attempted to give absolute values for the presence of the different phylogenetic groups. However, given the high reproducibility of DGGE fingerprints (Schauer et al. 2000, Díez et al. 2001), changes in band intensities are likely due to relative changes in the abundances of the corresponding populations. In addition, several authors have shown a correlation between the abundance of morphologically distinct organisms and the corresponding DGGE signal (Nübel et al. 1999, Riemann et al. 1999, Casamayor et al. 2000, 2002). In our study, when we related the relative DGGE band intensity for Synechococcus and Prochlorococcus to their relative (with respect to total prokaryotes) abundance estimated by flow cytometry, we found remarkably similar trends during the annual cycle. Correlations were highly significant both for Synechococcus $(\mathrm{R}=0.832, \mathrm{p}<0.0005)$ and for Prochlorococcus ( $\mathrm{R}=0.822$, $\mathrm{p}<0.0005$ ) (Fig. 8). However, the PCR-DGGE approach overestimated between 2 and 3 times the relative abundance of these cyanobacterial populations. Overall, it appears that relative band intensities in DGGE fingerprints are informative for comparative purposes and can be used to follow relative changes of particular populations, but may be poor indicators of absolute abundances.

Another constraint of the DGGE approach is that phylogenetic analysis of band sequences is limited by short sequences, which are sometimes also of poor quality. The sequences obtained in this study were ca. 400 to $540 \mathrm{bp}$ long and include some of the most variable regions of the 16S rRNA gene. They are suitable to determine their closest relatives in DNA databases and to relate them to well established phylogenetic groups 
(Stackebrandt \& Rainey 1995). We made sure we were sequencing the intended bands by reamplification and DGGE to verify realignment with the originally excised band. In 6 instances we found more than one band after the reamplification step, probably due to contaminating DNA, and the intended band was again reexcised and reamplified. In a few cases, however, we were not able to obtain sequence data of a reasonable quality. This is an inherent problem of DGGE and may be partly due to the presence of different sequences in 1 band (Bano \& Hollibaugh 2002), and the solution would be to clone excised bands and analyze several of the clones. Even with all these caveats, and assuming that the same band in different lanes always has the same sequence (a likely scenario when we analyze samples from the same system), around $80 \%$ of the total band intensity in the Blanes Bay DGGE gel could be attributed to sequenced phylotypes.

\section{Variability of the bacterial assemblage}

The NMDS diagram (Fig. 4) representing the bacterial composition during the Blanes Bay seasonal cycle suggests rather gradual changes of the assemblage during most of the year. In general, abrupt changes in assemblage composition could not be found either in the primary data (Fig. 3) or in the NMDS visualization (Fig. 4). Most bacterial populations appeared in a given sample, remained for several months and then disappeared. Similar results have been obtained following coastal bacterial assemblages during a spring bloom (Riemann \& Middelboe 2002).

Our study combines a monthly sampling during most of the year with a weekly sampling during late winter, when the bacterial community was expected to change faster due to the phytoplankton bloom and the concomitant increase of bacterial numbers. However, the gradual changes observed during the year are comparable during this period (changes between weekly samples being smaller). Thus, it seems that our temporal scale of sampling was appropriate and the forces that shape the bacterial assemblage structure operate at monthly scales. This is much longer than the expected doubling time of the bacterial assemblage (in the order of days), indicating a relatively steady state in bacterial assemblage composition for relatively long periods of time, during which growth and losses of each population compensate each other to keep the taxonomic structure stable. We postulate that over the year, the main factors affecting bacterial composition are the change in DOM supply mediated by different algal populations and the different temperature optima of bacterial populations. Top-down factors, which can operate in a much shorter time scale, do not seem to shape bacterial composition in this marine environment. In fact, top-down factors might contribute to maintain the stable community structure by consuming the bacteria produced. This would be consistent with current views of protozoan grazing removal of the actively growing fraction of the bacterioplankton (Šimek et al. 1999, Suzuki 1999) and the 'killing the winner' strategy of viruses (Thingstad \& Lignell 1997). Nevertheless, we cannot rule out that minor members of the bacterial assemblage undergo rapid temporal changes as suggested by other authors (Jaspers et al. 2001).

Over the year, the modest changes in the presence of $\alpha$-Proteobacteria and CFB (Fig. 6), which suggests a rather stable general structure of the bacterioplankton, contrasts with a clear succession of populations within each phylogenetic group (Fig. 7). Interestingly, sometimes the populations that substitute each other are very similar phylogenetically (Fig. 5). This is the case for Bands BL98-13 (winter) and Bands BL98-10 and BL98-13 (summer) within CFB, Bands BL98-28 (winter/spring) and BL98-27 (summer) within the Roseobacter clade, and Bands BL98-49 (winter/spring) and BL98-48 (summer/fall) within Synechococcus. This substitution of similar populations with time has been observed in a freshwater lake for purple sulfur bacteria, cyanobacteria and CFB (Casamayor et al. 2002). It is also known that closely related phylotypes within the SAR11 cluster (Field et al. 1997), the Group I marine archaea (Massana et al. 2000) or the marine Prochlorococcus (Moore et. al. 1998), occupy different depths in the water column. In the case of Prochlorococcus, it has been demonstrated that populations living at different depths have different light dependent physiologies. The coexistence of high- and lowlight ecotypes allows the survival of the whole group over a broader depth range than would be possible for a physiologically and genetically homogenous population. We do not know which mechanisms are behind the microdiversity found in our seasonal study, but we can postulate that temperature, which fluctuates from 13 to $27^{\circ} \mathrm{C}$, or the different availability of DOM during the seasons, are the determinant factors. Moreover, it could also be that these organisms, with very similar $16 \mathrm{~S}$ rDNA, are physiologically very different (Béjà et al. 2002).

\section{Phylogenetic composition of bacterioplankton}

Our data indicate that different populations of $\alpha$-Proteobacteria (mostly from the Roseobacter clade), CFB and cyanobacteria were very important throughout the year in Blanes Bay. FISH data obtained in the same site some years later (unpubl. results) point to Roseobacter 
and CFB as very significant components of this system (together they explain up to $60 \%$ of bacterial cells), whereas SAR11 cells were not detected. Rappé et al. (1997) studied the coastal picoplankton off Cape Hatteras (North Atlantic) in a single genetic library. Of the 112 bacterial 16S rRNA clones analyzed, almost half were related to $\alpha$-Proteobacteria (21\% to Roseobacter clade, $12 \%$ to SAR11, and $12 \%$ to SAR 116$), 40 \%$ to $\gamma$-Proteobacteria (mostly SAR86) and $10 \%$ to $\beta$-Proteobacteria. A few clones were related to $\mathrm{CFB}$ and the marine Gram-positive cluster, but no cyanobacterial clone was found. Similar results were obtained in clone libraries constructed from samples taken off the Oregon Coast (Suzuki et al. 1997), Great South Bay, the North Atlantic (Kelly \& Chistoserdov 2001) and from several stations off the California Coast (Cottrell \& Kirchman 2000b), with the exception that the latter 2 studies found more cyanobacteria and CFB clones. Therefore, the relative importance of Roseobacter in Blanes agrees with the results obtained in most marine systems investigated, regardless of the molecular technique used in each study. The relative importance of CFB in Blanes Bay, in turn, agrees with results obtained with FISH in a variety of systems and is consistent with the finding that many clone libraries were biased against this important marine bacterial group (Kirchman 2002).

The absence of the environmental clusters SAR11 and SAR86 in our study is remarkable. This could have been due to an internal mismatch of primer $907 \mathrm{rC}$ with most $\gamma$-Proteobacteria (including SAR86) (Schäfer et al. 2001) and the SAR11 cluster. It has been shown that the substitution of 1 base in primer 907r can result in totally different DGGE fingerprints (Schäfer et al. 2001). However, when we compared the fingerprints shown here for primer $907 \mathrm{rC}$ with those obtained with primer $907 \mathrm{rM}$, which has an ambiguity in the critical position and should detect both SAR11 and SAR86 as well as the other bacteria, we obtained almost identical fingerprints (data not shown). In addition, using the same PCR and DGGE conditions with offshore Mediterranean samples, we detected 3 bands related to SAR11 that accounted for $16 \%$ of band intensity, on average (unpubl. data). Thus, we did not find SAR11 or SAR86 phylotypes, nor did we find any $\beta$-Proteobacteria, a group often found in other coastal systems (Rappé et al. 1997, Kelly \& Chistoserdov 2001). These bacteria may be absent from Blanes Bay, they may be present in very low and undetectable amounts, or they may be represented by the unsequenced bands. The absence of $\beta$-Proteobacteria might be due to the limited freshwater influence in the Bay characteristic of this Mediterranean region. The ecological condition favoring Roseobacter and CFB against SAR11 and SAR86 deserves further investigation.
Application of DGGE in the present seasonal study revealed the time scale for replacement of dominant members of the bacterioplankton assemblage. The identification of the phylotypes present and their temporal succession is a necessary first step to understand their role in the functioning of the system. Whether these identified dominant members are in fact the 'key players' driving the major part of biogeochemical cycling remains to be tested using single cell analysis techniques, such as flow cytometry or microautoradiography combined with FISH (Gray \& Head 2001). Although renovated culturing efforts are giving unsuspected results (Rappé et al. 2002), many marine bacteria and archaea still remain uncultured and are only known from their 16S rDNA sequences. The only means available to elucidate their role in the environment is their culture-independent characterization combined with methods to determine their metabolic activity in situ.

Acknowledgements. Anselm and his 'Margarita' took us off the coast in Blanes Bay. Beatriz Díez, Emilio O. Casamayor and Núria Molist helped during sampling. We thank Pep Gasol for his help with processing the flow cytometry samples and his critical comments to the manuscript. Jordi opened the way to unbeknownst resources. This work was supported by EU projects PICODIV (EVK3-CT1999-00021) and BASICS (EVK3-CT-2002-00078), and the Spanish DGICYT project MICRODIFF (REN2001-2120-MAR) .

\section{LITERATURE CITED}

Acinas SG, Rodríguez-Valera F, Pedrós-Alió C (1997) Spatial and temporal variation in marine bacterioplankton diversity as shown by RFLP fingerprinting of PCR amplified 16S rDNA. FEMS Microbiol Ecol 24:27-40

Altschul SF, Madden TL, Schäffer AA, Zhang J, Zhang Z, Miller W, Lipman DJ (1997) Gapped BLAST and PSIBLAST: a new generation of protein database search programs. Nucleic Acids Res 25:3389-3402

Bano N, Hollibaugh JT (2002) Phylogenetic composition of bacterioplankton assemblages from the Arctic Ocean. Appl Environ Microbiol 68:505-518

Béjà O, Koonin EV, Aravind L, Taylor LT and 6 others (2002) Comparative genomic analysis of archaeal gentoypic variants in a single population and in two different oceanic provinces. Appl Environ Microb 68:335-345

Casamayor EO, Schäfer H, Bañeras L, Pedrós-Alió C, Muyzer G (2000) Identification of and spatio-temporal differences between microbial assemblages from two neighboring sulfurous lakes: comparison by microscopy and denaturing gradient gel electrophoresis. Appl Environ Microbiol 66:499-508

Casamayor EO, Pedrós-Alió C, Muyzer G, Amann R (2002) Microheterogeneity in $16 \mathrm{~S}$ ribosomal DNA-defined bacterial populations from a stratified planktonic environment is related to temporal changes and to ecological adaptations. Appl Environ Microbiol 68:1706-1714

Cottrell MT, Kirchman DL (2000a) Natural assemblages of marine Proteobacteria and members of the Cytophaga- 
Flavobacter cluster consuming low- and high-molecularweight dissolved organic matter. Appl Environ Microbiol 66:1692-1697

Cottrell MT, Kirchman DL (2000b) Community composition of marine bacterioplankton determined by 16S rRNA gene clone libraries and fluorescence in situ hybridization. Appl Environ Microbiol 66:5116-5122

Díez B, Pedrós-Alió C, Marsh TL, Massana R (2001) Application of denaturing gradient gel electrophoresis (DGGE) to study the diversity of marine picoeukaryotic assemblages and comparison of DGGE with other molecular techniques. Appl Environ Microbiol 67:2942-2951

Duarte CM, Agustí S, Kennedy H, Vaqué D (1999) The Mediterranean climate as a template for Mediterranean marine ecosystems: the example of the northeast Spanish littoral. Prog Oceanogr 44:245-270

Fandino LB, Riemann L, Steward GF, Long RA, Azam F (2001) Variations in bacterial community structure during a dinoflagellate bloom analyzed by DGGE and 16S rDNA sequencing. Aquat Microb Ecol 23:119-130

Field KG, Gordon D, Wright T, Rappé M, Urback E, Vergin K, Giovannoni SJ (1997) Diversity and depth-specific distribution of SAR11 cluster rRNA genes from marine planktonic bacteria. Appl Environ Microbiol 63:63-70

Gasol JM, del Giorgio PA (2000) Using flow cytometry for counting natural planktonic bacteria and understanding the structure of planktonic bacterial communities. Sci Mar 64:197-224

Giovannoni SJ, Rappé MS (2000) Evolution, diversity, and molecular ecology of marine prokaryotes. In: Kirchman DL (ed) Microbial ecology of the oceans. Wiley-Liss, New York, p 47-84

Gray ND, Head IM (2001) Linking genetic identity and function in communities of uncultured bacteria. Environ Microbiol 3:481-492

Jaspers E, Nauhaus K, Cypionka H, Overmann J (2001) Multitude and temporal variability of ecological niches as indicated by the diversity of cultivated bacterioplankton. FEMS Microbiol Ecol 36:153-164

Kelly KM, Chistoserdov AY (2001) Phylogenetic analysis of the succession of bacterial communities in the Great South Bay (Long Island). FEMS Microbiol Ecol 35:85-95

Kirchman DL (2002) The ecology of Cytophaga-Flavobacteria in aquatic environments. FEMS Microbiol Ecol 39:91-100

Lindström ES (1998) Bacterioplankton community composition in a boreal forest lake. FEMS Microbiol Ecol 27: 163-174

Maidak BL, Cole JR, Lilburn TG, Parker CT Jr and 6 others (2001) The RDP-II (Ribosomal Database Project). Nucleic Acids Res 29:173-174

Masó M, Tintoré J (1991) Variability of the shelf water off the northeast Spanish coast. J Mar Syst 1:441-450

Massana R, DeLong EF, Pedrós-Alió C (2000) A few cosmopolitan phylotypes dominate planktonic archaeal assemblages in widely different oceanic provinces. Appl Environ Microbiol 66:1777-1787

Moore LR, Rocap G, Chisholm SW (1998) Physiology and molecular phylogeny of coexisting Prochlorococcus ecotypes. Nature 393:464-467

Murray AE, Hollibaugh JT, Orrego C (1996) Phylogenetic composition of bacterioplankton from two California estuaries compared by denaturing gradient gel electrophoresis of $16 \mathrm{~S}$ rDNA fragments. Appl Environ Microbiol 62: $2676-2680$

Murray AE, Preston CM, Massana R, Taylor LT, Blakis A, Wu K, DeLong EF (1998) Seasonal and spatial variability of bacterial and archaeal assemblages in the coastal waters near Anvers Island, Antarctica. Appl Environ Microbiol 64:2585-2595

Muyzer G, Brinkhoff T, Nübel U, Santegoeds C, Schäfer H, Wawer C (1997) Denaturing gradient gel electrophoresis (DGGE) in microbial ecology. In: Akkermans ADL, van Elsas JD, de Bruijn FJ (eds) Molecular microbial ecology manual. Kluwer Academic, Dordrecht, p 1-27

Nübel U, Garcia-Pichel F, Kühl M, Muyzer G (1999) Quantifying microbial diversity: morphotypes, 16S rRNA genes, and carotenoids of oxygenic phototrophs in microbial mats. Appl Environ Microbiol 65:422-430

Olsen RJ, Zettler ER, DuRand MD (1993) Phytoplankton analysis using flow cytometry. In: Kemp PF, Sherr BF, Sherr EB, Cole JJ (eds) Handbook of methods in aquatic microbial ecology. Lewis Publishers, Boca Raton, FL, p 175-186

Paul JH, Myers B (1982) Fluorometric determination of DNA in aquatic microorganisms by use of Hoechst 33258. Appl Environ Microbiol 43:1393-1399

Pernthaler J, Glöckner FO, Unterholzner S, Alfreider A, Psenner R, Amann R (1998) Seasonal community and population dynamics of pelagic bacteria and archaea in a high mountain lake. Appl Environ Microbiol 64:4299-4306

Pinhassi J, Hagström $\AA$ (2000) Seasonal succession in marine bacterioplankton. Aquat Microb Ecol 21:245-256

Rappé MS, Kemp PK, Giovannoni SJ (1997) Phylogenetic diversity of marine coastal picoplankton 16S rRNA genes cloned from the continental shelf off Cape Hatteras, North Carolina. Limnol Oceanogr 42:811-826

Rappé MS, Connon SA, Vergin KL, Giovannoni SJ (2002) Cultivation of the ubiquitous SAR11 marine bacterioplankton clade. Nature 418:630-633

Riemann L, Middelboe M (2002) Stability of bacterial and viral community compositions in Danish coastal waters as depicted by DNA fingerprinting techniques. Aquat Microb Ecol 27:219-232

Riemann L, Steward GF, Fandino LB, Campbell L, Landry MR, Azam F (1999) Bacterial community composition during two consecutive NE Monsoon periods in the Arabian Sea studied by denaturing gradient gel electrophoresis (DGGE) of rRNA genes. Deep-Sea Res 46:1791-1811

Schäfer H, Bernard L, Courties C, Lebaron P and 7 others (2001) Microbial community dynamics in Mediterranean nutrient-enriched seawater mesocosms: changes in the genetic diversity of bacterial populations. FEMS Microbiol Ecol 34:243-253

Schauer M, Massana R, Pedrós-Alió C (2000) Spatial differences in bacterioplankton composition along the Catalan coast (NW Mediterranean) assessed by molecular fingerprinting. FEMS Microbiol Ecol 33:51-59

Šimek J, Kojecká P, Nedoma J, Hartman P, Vrba J, Dolan JR (1999) Shifts in bacterial community composition associated with different microzooplankton size fractions in a eutrophic reservoir. Limnol Oceanogr 44:1634-1644

Stackebrandt E, Rainey FA (1995) Partial and complete 16S rDNA sequences, their use in generation of $16 \mathrm{~S}$ rDNA phylogenetic trees and their implications in molecular ecological studies. In: Akkermans ADL, van Elsas JD, de Bruijn FJ (eds) Molecular microbial ecology manual. Kluwer Academic, Dordrecht, p 1-17

Suzuki MT (1999) Effect of protistan bacterivory on coastal bacterioplankton diversity. Aquat Microb Ecol 20:261-272

Suzuki MT, Giovannoni SJ (1996) Bias caused by template annealing in the amplification of mixtures of 16S rRNA genes by PCR. Appl Environ Microbiol 62:625-630

Suzuki MT, Rappé M, Haimberger ZW, Winfield H, Adair N, Ströbel J, Giovannoni SJ (1997) Bacterial diversity among 
small-subunit rRNA gene clones and cellular isolates from the same seawater sample. Appl Environ Microbiol 63: 983-989

Thingstad TF, Lignell R (1997) Theoretical models for the control of bacterial growth rate, abundance, diversity and carbon demand. Aquat Microb Ecol 13:19-27

van Hannen EJ, Zwart G, van Agterveld MP, Gons HJ, Ebert J, Laanbroeck HJ (1999) Changes in bacterial and eukaryotic community structure after mass lysis of filamentous cyanobacteria associated with viruses. Appl Environ Microbiol 65:795-801

Vaqué D, Blough HA, Duarte CM (1997) Dynamics of ciliate abundance, biomass and community composition in an

Editorial responsibility: Jed Fuhrman,

Los Angeles, California, USA oligotrophic coastal environment (NW Mediterranean). Aquat Microb Ecol 12:71-83

von Witzingerode F, Göbel UB, Stackebrandt E (1997) Determination of microbial diversity in environmental samples: pitfalls of PCR-based rRNA analysis. FEMS Microbiol Rev 21:213-229

Yager PL, Connelly TL, Mortazavi B, Wommack KE, Bano N, Bauer JE, Opsahl S, Hollibaugh JT (2001) Dynamic bacterial and viral response to an algal bloom at subzero temperatures. Limnol Oceanogr 46:790-801

Yentsch CS, Menzel DW (1963) A method for the determination of phytoplankton chlorophyll and phaeophytin by fluorescence. Deep-Sea Res 10:221-231

Submitted: May 16, 2002; Accepted: December 10, 2002 Proofs received from author(s): February 10, 2003 